\title{
Vertuous Women Found: New England Ministerial Literature, 1668-1735
}

\section{Citation}

Ulrich, Laurel Thatcher. 1976. “Vertuous Women Found: New England Ministerial Literature, 1668-1735." American Quarterly 28 (1): 20-40.

\section{Published Version}

doi: $10.2307 / 2712475$

\section{Permanent link}

http://nrs.harvard.edu/urn-3:HUL.InstRepos:14123819

\section{Terms of Use}

This article was downloaded from Harvard University's DASH repository, and is made available under the terms and conditions applicable to Other Posted Material, as set forth at http:// nrs.harvard.edu/urn-3:HUL.InstRepos:dash.current.terms-of-use\#LAA

\section{Share Your Story}

The Harvard community has made this article openly available.

Please share how this access benefits you. Submit a story.

\section{Accessibility}




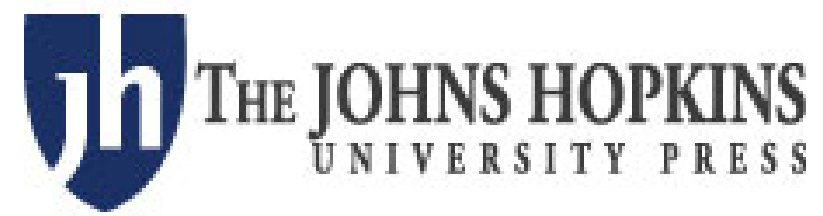

Vertuous Women Found: New England Ministerial Literature, 1668-1735

Author(s): Laurel Thatcher Ulrich

Source: American Quarterly, Vol. 28, No. 1 (Spring, 1976), pp. 20-40

Published by: The Tohns Hopkins University Press

Stable URL: http://www.jstor.org/stable/2712475

Accessed: 07/11/2014 16:37

Your use of the JSTOR archive indicates your acceptance of the Terms \& Conditions of Use, available at http://www.jstor.org/page/info/about/policies/terms.jsp

JSTOR is a not-for-profit service that helps scholars, researchers, and students discover, use, and build upon a wide range of content in a trusted digital archive. We use information technology and tools to increase productivity and facilitate new forms of scholarship. For more information about JSTOR, please contact support@ jstor.org.

The Johns Hopkins University Press is collaborating with JSTOR to digitize, preserve and extend access to American Quarterly. 


\title{
VERTUOUS WOMEN FOUND: NEW ENGLAND MINISTERIAL LITERATURE, 1668-1735
}

\author{
LAUREL THATCHER ULRICH \\ University of New Hampshire
}

COTTON MATHER CALLED THEM "THE HIDDEN ONES." THEY NEVER preached or sat in a deacon's bench. Nor did they vote or attend Harvard. Neither, because they were virtuous women, did they question God or the magistrates. They prayed secretly, read the Bible through at least once a year, and went to hear the minister preach even when it snowed. Hoping for an eternal crown, they never asked to be remembered on earth. And they haven't been. Well-behaved women seldom make history; against Antinomians and witches, these pious matrons have had little chance at all. Most historians, considering the domestic by definition irrelevant, have simply assumed the pervasiveness of similar attitudes in the seventeenth century. Others, noting the apologetic tone of Anne Bradstreet and the banishment of Anne Hutchinson, have been satisfied that New England society, while it valued marriage and allowed women limited participation in economic affairs, discouraged their interest in either poetry or theology. For thirty years no one has bothered to question Edmund Morgan's assumption that a Puritan wife was considered "the weaker vessel in both body and mind" and that "her husband ought not to expect too much from her." John Winthrop's famous letter on the insanity of bookish Mistress Hopkins has been the quintessential source: ". . . if she had attended her household affairs, and such things as belong to women, and not gone out of

\footnotetext{
${ }^{1}$ Edmund S. Morgan, The Puritan Family: Religion and Domestic Relations in SeventeenthCentury New England (New York: Harper and Row, 1966), p. 44. Recent works continue to rely on Morgan's study, which was first published in 1944. See, for example, John Demos, $A$ Little Commonwealth: Family Life in Plymouth (New York: Oxford Univ. Press, 1970), p. 98. Morgan's description of male dominance within a loving marriage is consistent with descriptions taken from English prescriptive literature in Louis B. Wright, Middle-Class Culture in Elizabethan England (Chapel Hill, N.C.: Univ. of North Carolina Press, 1935), chapter VII, and in Charles H. and Katherine George, The Protestant Mind of the English Reformation, 1570-1640 (Princeton, N.J.: Princeton Univ. Press, 1961), chapter 7.
} 
her way and calling to meddle in such things as are proper for men, whose minds are stronger, etc., she had kept her wits." 2

Yet there is ample evidence in traditional documents to undermine these conclusions, at least for the late seventeenth and early eighteenth centuries. For the years between 1668 and 1735, Evans' American Bibliography lists 55 elegies, memorials, and funeral sermons for females plus 15 other works of practical piety addressed wholly or in part to women. ${ }^{3}$ Although historians have looked at such popular works as Cotton Mather's Ornaments for the Daughters of Zion, they have ignored the rest. ${ }^{4}$ Thus, New England's daughters remain hidden despite the efforts of her publishing ministry. True, a collection of ministerial literature cannot tell us what New England women, even of the more pious variety, were really like. Nor can it describe what "most Puritans" thought of women. It can tell us only what qualities were publicly praised in a specific time by a specific group of men. Yet, in a field which suffers from so little data, there is value in that. A handful of quotations has for too long defined the status of New England's virtuous women. This interesting collection deserves a closer look.

Although 27 of the 70 titles are by Cotton Mather (who wrote more of everything in the period), the remaining 43 are the work of 21 authors. They range from a single sermon by Leonard Hoar, his only published work, to the six poems for women written over a 25 -year period by ubiquitous elegist John Danforth. They include four English works republished in America. Only 12 of the titles were printed before 1700, but two others, Samuel Willard's short discourse on marriage from his Complete Body of Divinity, posthumously published in 1726, and Hugh Peter's A Dying Father's Last Legacy, first reprinted in Boston in 1717, originated earlier. Peter's treatise,

\footnotetext{
${ }^{2}$ The Winthrop quote appears in Morgan (p. 44) as in many lesser summaries of Puritan attitudes toward women from Thomas Woody, A History of Women's Education in the United States, Vol. I (New York: Science Press, 1929), pp. 106-07, to Lyle Koehler, "The Case of the American Jezebels: Anne Hutchinson and Female Agitation During the Years of Antinomian Turmoil, 1636-1640," William and Mary Quarterly, 3rd Ser., 31 (Jan. 1974), p. 58. Koehler's article exemplifies the common imbalance in favor of deviant women.

${ }^{3}$ Charles Evans, American Bibliography: A Chronological Dictionary of all Books, Pamphlets and Periodical Publications Printed in the USA, 1639-1820 (New York: P. Smith, 1941); Roger Bristol, Supplement to Charles Evans' American Bibliography (Charlottesville, Va.: Univ. Press of Virginia, 1970).

${ }^{4}$ Mary Sumner Benson, in Women in Eighteenth-Century America (New York: Columbia Univ. Press, 1935), quotes extensively from Mather's Ornaments, using it as evidence that he believed in the "proper submission of women." Page Smith draws the opposite conclusion from the same document in Daughters of the Promised Land (Boston: Little, Brown, 1970), pp. $47 \mathrm{ff}$. Two of the three main sources for Edmund Morgan's description of marital ethics belong to this group of materials: Willard's Complete Body of Divinity and Wadsworth's The Well-Ordered Family, although he quotes rather selectively from them. William Andrews, “The Printed Funeral Sermons of Cotton Mather," Early American Literature, 5 (Fall 1970), pp. 24-44, notes the high percentage of sermons on females and attempts some analysis of the materials but without relating it to the wider corpus of ministerial literature.
} 
written just before his execution, is especially interesting as a link to the first generation of New Englanders.

In spite of personal idiosyncracies and the acknowledged predominance of Mather, this literature is remarkably consistent. Thus, a crude woodcut decorating a broadside published for Madam Susanna Thacher in 1724 is identical to that ornamenting an elegy for Lydia Minot published in 1668. Nor are doctrinal distinctions of any consequence. Benjamin Colman could differ with his brethren over the precise meaning of New England, for example, yet share with them a common attitude toward women. ${ }^{5}$ Because these works are so much of a piece, however, subtle shifts in emphasis between authors and across time become significant. A patient examination of this seemingly static and formulaic material reveals nuances in ministerial thought of considerable interest, demonstrating that for women's history, as for so many aspects of social history, the real drama is often in the humdrum.

In ministerial literature, as in public records, women became legitimately visible in only three ways: they married, they gave birth, they died. In the written materials, dying is by far the best documented activity. Although a minister might have had a specific woman in mind as he prepared an idealized portrait of the good wife for a wedding or espousal sermon or as he composed a comforting tract for parishioners approaching childbed, it is only in the funeral literature that he is free to name names and praise individual accomplishments. Not that a funeral sermon is ever very specific. Circumlocution, even a certain coyness in referring to "that excellent person now departed from us," is the rule. Still, it is a rare sermon that does not contain a eulogy, however brief. Some append fuller biographical sketches often containing selections from the writings of the deceased. ${ }^{6}$ From these materials a composite portrait emerges.

A virtuous woman sought God early. Hannah Meigs, who died in New London at the age of 22 , was typical. She began while still a child to pay attention in church, acquiring the habit of reading and praying at night when the rest of her family was asleep. Becoming preoccupied with her own sal-

\footnotetext{
${ }^{5}$ In his study of prescriptive literature in late seventeenth-century England, Levin L. Schucking noted a similar phenomenon. See The Puritan Family: A Social Study from the Literary Sources (London: Routledge and Kegan Paul, 1969), p. xiii. I have made no attempt to define the "Puritanism" of the authors. Although most of them belonged to the congregational majority, Samuel Myles was an Anglican. His eulogy for Elizabeth Riscarrick, though less detailed than many, follows the typical pattern.

${ }^{6}$ The funeral sermon with its accompanying biographical "lean-to" was a venerable form by this time. See William Haller, The Rise of Puritanism (New York: Harper, 1938), p. 101.
} 
vation, she bewailed her sinfulness, at last receiving an assurance of God's mercy. In the sickness which eventually claimed her, she submitted her will to God, from her death bed meekly teaching her brothers and sisters and other "Relatives, Acquaintances, \& Companions."7 Praise of early piety was not confined to sermons for young women. In his eulogy for Mary Rock, who died at the age of 80 , Cotton Mather devoted considerable space to her early religiosity and the wise education of her parents. ${ }^{8}$ The women eulogized typically found God before marriage, having been, in Danforth's phrase, first "Polish'd and Prepar'd" by pious parents. ${ }^{9}$

A virtuous woman prayed and fasted. Jane Colman was said to have lain awake whole nights mourning for sin, calling on God, praying. ${ }^{10} \mathrm{Mrs}$. Increase Mather regularly prayed six times a day. After her death her husband wrote a tribute to her from his study, a spot which had become endeared to him when he discovered in some of her private papers that during his four years absence in England she had "spent many whole Days (some Scores of them) alone with God there" in prayer and fasting for his welfare and that of her children. ${ }^{11}$ Thomas Foxcroft characterized a praying mother as "One that stood in the Breach to turn away wrath" and concluded that the death of such women was a bad omen for the community. ${ }^{12}$ Cotton Mather was fond of saying that good mothers travailed twice for their children, once for their physical birth, again for the spiritual. ${ }^{13}$

A virtuous woman loved to go to church. On the day of her death ailing Sarah Leveret went to hear the sermon even though the weather was bitter. When her friends tried to dissuade her, she answered: "If the Ministers can go abroad to Preach, certainly, it becomes the People to go abroad; and hear them." 14 Sarah was not alone among New England's pious matrons. The ministers who preached the funeral sermons for Anne Mason and Jane Steel both commented on the fact that they came to church even when they

${ }^{7}$ John Hart, The Nature and Blessedness of Trusting in God (New London, 1728), p. 45.

${ }^{8}$ Cotton Mather, Nepenthes Evangelicum ... A Sermon Occasion'd by the Death of a Religious Matron, Mrs. Mary Rock (Boston, 1713), p. 41.

${ }^{9}$ John Danforth, "An Elegy upon the much Lamented Decease of Mrs. Elizabeth Foxcroft," appended to Thomas Foxcroft's Sermon Preach'd at Cambridge after the Funeral of Mrs. Elizabeth Foxcroft (Boston, 1721), p. 53.

${ }^{10}$ Benjamin Colman, Reliquiae Turellae, et Lachrymae Paternae. Father's Tears over his Daughter's Remains ... to which are added, some Large Memoirs of her Life and Death by her Consort, the Reverend Mr. Ebenezer Turell (Boston, 1735), p. 116.

${ }^{11}$ Increase Mather, A Sermon Concerning Obedience \& Resignation To The Will of God in Everything (Boston, 1714), p. ii, p. 39.

${ }^{12}$ Foxcroft, Sermon Preach'd, pp. 14-15.

${ }^{13}$ This is a common theme throughout Mather's funeral sermons. A typical example is in Virtue in its Verdure. A Christian Exhibited as a Green Olive Tree ... with a character of the Virtuous Mrs. Abigail Brown (Boston, 1725), p. 23.

${ }^{14}$ Cotton Mather, Monica Americana, A Funeral-Sermon Occasioned by Death of Mrs. Sarah Leveret (Boston, 1705), p. 27. 
were ill. ${ }^{15}$ Jabez Fitch said of Mrs. Mary Martin: "The feet of those that brought the glad Tidings of the Gospel, were always beautiful in her Eyes, and it was her great Delight to attend on the Ministry of the Word." 16

A virtuous woman read. Throughout the eulogies reading is mentioned as often as prayer, and the two activities are occasionally linked as in John Danforth's praise of Hannah Sewall:

Observing Ladys must keep down their Vail, 'Till They're as Full of Grace, \& Free from Gall, As Void of Pride, as High in Vertue Rare As much in Reading, and as much in Prayer. ${ }^{17}$

After her children were grown, Maria Mather took renewed interest in reading the scriptures, more than doubling the prescribed pace by reading the Bible through twice in less than a year. ${ }^{18}$ Her daughter Jerusha was a great reader of history and theology as well as scripture, having been given eyesight so excellent she could read in dim light. ${ }^{19}$ Katharin Mather, Cotton's daughter, went beyond her grandmother and her aunt. She mastered music, penmanship, needlework, the usual accomplishments of a gentlewoman, "To which she added this, that she became in her childhood a Mistress of the Hebrew Tongue." 20

A virtuous woman conversed. Mourning for Elizabeth Hatch, Joseph Metcalf lamented nothing so much as the loss of her pious discourse. ${ }^{21}$ For John Danforth, Elizabeth Hutchinson's conversation was "sweeter than Hybla's Drops," while for Cotton Mather, the "fruitfulness" of Mary Rock's "Religious Conferences" made her sick room "A little AntiChamber of Heaven."22 James Hillhouse said his mother could converse "on many subjects with the Grandees of the World, and the Masters of Eloquence" yet she was not haughty. "Her incessant and constant Reading, with her good Memory, and clear Judgment, made her expert (even to a degree) in the Bible. Insomuch, that she was capable on many occasions,

${ }^{15}$ James Fitch, Peace the End of the Perfect and Upright (Cambridge, 1672), p. 12; Benjamin Colman, The Death of God's Saints Precious in His Sight (Boston, 1723), p. 23.

${ }^{16}$ Jabez Fitch, Discourse on Serious Piety. A Funeral Sermon ... upon the Death of Mrs. Mary Martyn (Boston, 1725), p. 18.

${ }^{17}$ John Danforth, "Greatness \& Goodness Elegized, In a Poem upon the Much Lamented Decease of the Honourable \& Vertuous Madam Hannah Sewall” (Boston, 1717), Broadside, p. 1. $33 \mathrm{ff}$.

${ }^{18}$ Increase Mather, $A$ Sermon Concerning Obedience, p. ii.

${ }^{19}$ Cotton Mather, Memorials of Early Piety (Boston, 1711), pp. 3-4, 13.

20"An Account of Mrs. Katharin Mather by Another Hand," in Cotton Mather, Victorina: A Sermon Preach'd on the Decease and at the Desire of Mrs. Katharin Mather (Boston, 1717), p. 50.

${ }^{21}$ [Joseph Metcalf,] "Tears Dropt at the Funeral of ... Mrs. Elizabeth Hatch" (Boston, 1710), Broadside.

${ }^{22}$ John Danforth, "Honour and Vertue Elegized in a Poem Upon an Honourable, Aged, and Gracious Mother in Israel”' (Boston, 1713), Broadside; Cotton Mather, Nepenthes, pp. 45-46. 
very seasonably and suitably to apply it, and that with great facility and aptness, to the various Subjects of Discourse, that offered themselves." ${ }^{23}$ James Fitch said that if he were to "rehearse the many Spiritual, Weighty, and Narrow Questions \& Discourses" he had heard from Anne Mason, "it would fill up a large book." ${ }^{24}$ Benjamin Wadsworth praised Bridget Usher for promoting "pinus and savoury Discourse." ${ }^{25}$ Godly matrons were meant to be heard.

A virtuous woman wrote. A quill as well as a distaff was proper to a lady's hand. Despite eight pregnancies in ten years, Katharin Willard was such a good manager and so industrious that she was "hindred not from the Use of her Pen, as well as of her Needle." ${ }^{26}$ One form of writing was simply taking notes in church. Mary Terry wrote down the main points of the preacher's sermon, recalling the whole thing later from her notes, a habit which had apparently become less common by Foxcroft's time, for he commented that aged Bridget Usher and her associates had "practiced (even to the last) the good old way of writing after the Minister. They were swift to hear; and by this laudable (but not too unfashionable) Method, took care to hear for the time to come, as the Prophet Speaks." 27

In preaching a funeral sermon Cotton Mather often included excerpts from the woman's writings. In Elizabeth Cotton's, for example, he drew from writings at several stages of her life, telling his audience that one of these selections was "so expressive and so Instructive, that it may well pass for the Best part of my Sermon, if I now give to you all, and particularly the Daughters of our Zion, the Benefit of hearing it Read unto you." ${ }^{28}$ In 1711 he edited a selection of the writings of his sister Jerusha and published them with an introduction as Memorials of Early Piety. Such a practice was not uncommon. In 1681, Sarah Goodhue's husband published The Copy of $A$ Valedictory and Monitory Writing, a letter of "sage counsel" and "pious instructions" which she had written for her family and hidden, having had a premonition of her death in childbirth. ${ }^{29}$ Grace Smith's legacy to her

${ }^{23}$ James Hillhouse, A Sermon Concerning the Life, Death, and Future State of Saints (Boston, 1721), pp. 112, 117. Although Hillhouse's sermon was published in Boston after he had settled there, it was originally preached in Ireland.

${ }^{24}$ James Fitch, Peace, p. 11.

${ }^{25}$ Thomas Foxcroft, The Character of Anna, The Prophetess Consider'd and Apply'd (Boston, 1723), from the Preface by Benjamin Wadsworth, p. ii.

${ }^{26}$ Cotton Mather, El-Shaddai . . A brief Essay ... Produced by the Death of That Virtuous Gentlewoman, Mrs. Katharin Willard (Boston, 1725), p. 22.

${ }^{27}$ Thomas Reynolds, Practical Religion Exemplify'd In The Lives of Mrs. Mary Terry . . and Mrs. Clissould (Boston, 1713), p. 4; and Foxcroft, Anna, p. 14.

${ }^{28}$ Cotton Mather, Ecclesiae Monilia. The Peculiar Treasure of the Almighty King Opened Whereof one is more particularly Exhibited in the Character of Mrs. Elizabeth Cotton (Boston, 1726), p. 25.

${ }^{29}$ Sarah Goodhue, The Copy of a Valedictory and Monitory Writing . . Directed to her Husband and Children, with other Near Relations and Friends, reprinted in Thomas Franklin 
children was supposedly "taken from her lips by the Minister of that Town where she died," a strange statement since it included in addition to predictable paragraphs of advice and motherly proverbs, two long passages in verse written in iambic tetrameter with a rather complex internal rhyme scheme. ${ }^{30}$ Like the others, she had obviously been sharpening her pen after the spinning was done.

A virtuous woman managed well. Increase Mather said his father's greatest affliction was the death of his wife, "Which Afflication was the more grievous, in that she being a Woman of singular Prudence for the Management of Affairs, had taken off from her Husband all Secular Cares, so that he wholly devoted himself to his Study, and to Sacred Imployments." ${ }_{31}$ Women were praised in the funeral sermons not only for being godly but for being practical. Even the saintly Jerusha Oliver was not above dabbling in investments. "When she sent (as now and then she did) her Little Ventures to Sea, at the return she would be sure to lay aside the Tenth of her gain, for Pious Uses." 32

Anne Eliot's talents, which included nursing, were so valued that Danforth almost credited her with holding up the world:

Haile! Thou Sagacious \& Advant'rous Soul!
Haile, Amazon Created to Controll
Weak Nature's Foes, \& T'take her part,
The King of Terrours, Thou, (till the command
Irrevocable came to Stay thy Hand,)
Didst oft Repel, by thy Choice Art:
By High Decree
Long didst thou stand
An Atlas, in Heav'n's Hand
To th' World to be.

Mrs. Eliot, like many of her sisters, was no less pious as an "Atlas."

A virtuous woman submitted to the will of God. Increase Mather told the story of a "Person of Quality" whose only son contracted smallpox. She called in the ministers to pray for him. When they prayed that if by God's will the child should die the mother would have the strength to submit, she interrupted, crying: "If He will Take him away; Nay, He shall then Tear him away." The child died. Sometime later the mother became pregnant,

Water, Ipswich in the Massachusetts Bay Colony (Ipswich, Mass.: Ipswich Historical Society, 1905), pp. 519-24.

${ }^{30}$ Grace Smith, The Dying Mother's Legacy, or the Good and Heavenly Counsel of that Eminent and Pious Matron (Boston, 1712).

${ }^{31}$ Increase Mather, The Life and Death of Richard Mather (Cambridge, 1670), p. 25.

${ }^{32}$ Cotton Mather, Memorials of Early Piety, p. 45.

${ }^{33}$ John Danforth, "A Poem Upon the Triumphant Translation of a Mother in Our Israel," appended to Kneeling to God (Boston, 1697), p. 64. 
but when the time for delivery arrived the child would not come and was consequently "Violently Torn from her; so she Died." ${ }^{4}$ For the godly woman rebellion was not worth the risks. She learned to submit to God, meekly acquiescing to the deaths of husband and children and ultimately to her own as well. Only one minister suggested that a departed sister was less than patient in her final sickness and Samuel Myles cautioned his reader lest he "Uncharitably, and Unchristianly impute that to the Person, which was justly chargeable on the Disease." ${ }^{35}$ Cotton Mather's women were typically terrified of death until it approached, then they triumphed over the "King of Terrours." Jerusha Oliver sang for joy and sent a message to her sister in Roxbury telling her not to be afraid to die. ${ }^{36}$ Rebeckah Burnet, age 17, expired crying, "Holy, Holy, Holy_Lord Jesus, Come unto Me!" ${ }^{37}$ In her illness, Abiel Goodwin heard voices and music and was transported by the tolling of funeral bells. In her quieter moments she exhibited a wry sense of humor, agreeing with a visitor that, given her hydropical condition, she was "A going to Heaven by Water" and might soon sing that song with Jesus. ${ }^{38}$

Read directly, the qualities attributed to these women have little meaning. It is easy to conclude from the lavish praise bestowed upon them that they enjoyed an exalted position in the Puritan ethos. It is even more tempting to conclude the opposite, that the limited nature of their intellectual achievement and their continually lauded meekness and submission document a secondary role. It is helpful, then, to compare this portrait of a virtuous woman with a contemporary portrait of a godly man. Richard Mather, according to the eulogy written by his son Increase, found God early, prayed often, read the scriptures, and though he was learned "was exceeding low and little in his own eyes." Though well-educated, he was careful not to display his learning, and he always preached plainly. $\mathrm{He}$ loved to listen to sermons and in his last months continued to attend lectures in neighboring congregations until he was too sick to ride. "Yea and usually even to his old Age (as did Mr. Hildersham) he took notes from those whom he heard, professing that he found profit in it." He was patient in affliction, submitting to the will of God in death. ${ }^{39}$ The inference is clear. While a godly woman was expected to act appropriately in all the relations in which she found herself, to be a dutiful daughter, an obedient and faithful

\footnotetext{
${ }^{34}$ Increase Mather, Sermon Concerning Obedience, p. 34.

${ }^{35}$ Samuel Myles, Sermon Preach't At the Funeral of Mrs. Elizabeth Riscarrick (Boston, 1698).

${ }^{36}$ Cotton Mather, Memorials of Early Piety, p. 49.

${ }^{37}$ Cotton Mather, Light in Darkness, An Essay on the Piety Which by Rememb'ring the Many Days of Darkness, Will Change Them Into a Marvelous Light (Boston, 1724), p. 20.

${ }^{38}$ Cotton Mather, Juga, pp. 31-32.

${ }^{39}$ Increase Mather, Richard Mather, pp. 33, 34.
} 
wife, a wise parent and mistress, a kind friend, and a charitable neighbor, in her relationship with God she was autonomous. The portrait of Richard Mather, the first spiritual autobiography published in America, is duplicated in miniature in dozens of funeral sermons printed in Boston. But it didn't originate there. It is a pattern of godliness basic to the English reformed tradition. ${ }^{40}$ This much should be obvious to anyone familiar with Puritan literature, yet it bears repeating in a time when qualities such as "meekness" and "submissiveness" are presumed to have a sexual reference. In a very real sense there is no such thing as female piety in early New England: in preaching sermons for women, the ministers universally used the generic male pronouns in enlarging their themes, even when the text had reference to a scriptural Bathsheba or Mary; the same Christ-like bearing was required of both male and female.

Because dying is an individual rather than a social act, it is in the funeral literature that we see most clearly the equality of men and women before God. It is important, then, to try to determine whether this acknowledged spiritual equality impinged on the prescribed social roles described in the general works of practical piety.

In 1709 there appeared in Boston a reprint of a wedding sermon preached at Sherbourn in Dorsetshire by a nonconformist minister named John Sprint. Called The Bride-Woman's Counsellor, it virtually ignored the groom. Marital troubles, the author concluded, were mainly the fault of women anyway. "You women will acknowledge that Men can learn to command, and rule fast enough, which as Husbands they ought to do, but tis very rare to find that Women learn so fast to Submit and obey, which as Wives they ought to do." ${ }^{41}$ Like Sarah, women should call their husbands "Lord," never presuming to the familiarity of a Christian name lest they in time usurp his authority and place him under the discipline of an ApronString. Although women might make light of this instruction to obey, he continued, "I know not of any duty belonging to any Men or Women, in the

\footnotetext{
${ }^{40}$ See for example, Cotton Mather, $A$ Good Man Making $A$ Good End (Boston, 1698), on the death of a minister; and Thomas Foxcroft, A Brief Display of Mordecai's Excellent Character (Boston, 1727), on the death of a public official. For the English tradition (which placed less emphasis on early piety), see Haller, Rise of Puritanism, p. 93ff. Robert Middlekauff and David Hall both stress the prototypal quality of Richard Mather's biography. See The Mathers: Three Generations of Puritan Intellectuals, 1596-1728 (New York: Oxford Univ. Press, 1971), p. 101-02, and The Faithful Shepherd: A History of the New England Ministry in the Seventeenth Century (Chapel Hill, N.C.: Univ. of North Carolina Press, 1972), p. 179.

${ }^{41}$ John Sprint, The Bride-Woman's Counsellor, Being A Sermon Preached at a Wedding at Sherbourn, in Dorsetshire (Boston, 1709), p. 2.
} 
Whole Book of God, that is urged with more vehemency." Authority had been given to the husband as "absolutely and as peremptorily as unto Christ himself." 42

This is a remarkable document, all the more remarkable because in the whole corpus of materials printed in Boston there is nothing remotely like it in content or in tone. It makes a useful reference point for looking at three other works printed about the same time: Benjamin Wadsworth's The WellOrdered Family, 1712; William Secker's $A$ Wedding Ring, an English pamphlet reprinted in Boston in 1690, 1705, 1750, and 1773; and Samuel Willard's exposition of the fifth commandment in A Complete Body of Divinity, 1726.

Wadsworth's treatise must be looked at structurally. Like Sprint he reminded wives to "love, honour and obey," but his entire essay was organized around the notion of mutual responsibility, mutual caring. He listed seven duties of husbands and wives. The first six are reciprocal: to cohabit, to love one another, to be faithful to one another, to help one another, to be patient with one another, to honor one another. It is only with the seventh duty that there is any differentiation at all: the husband is to govern gently, the wife to obey cheerfully. It was thus within an ethic of mutual concern and sharing that Wadsworth developed the obedience theme, and he maintained the parallel structure of the essay even in these paragraphs. Both mates were scolded if they should lift up their hands against the other. A woman who struck her husband usurped not just his authority but that of God. A man who twitted his wife affronted not just a Woman but God. ${ }^{43}$ Wadsworth thus undercut the subjection of women to their husbands even as he upheld it.

The same tendency is apparent in Secker. $A$ Wedding Ring is a frothy bit of writing, a tiny little book which would have fitted a pocket or pouch. Its intention was not so much instruction as celebration, and it appropriated attractive quotations and metaphors at random, regardless of inconsistency. Although there are traditional proverbs enjoining submission, the great weight of the imagery falls on the side of equality. Eve is a "parallel line drawn equal" with Adam. A husband and wife are like two instruments making music, like two streams in one current, like a pair of oars rowing a boat to heaven (with children and servants as passengers), like two milch kine coupled to carry the Ark of God, two cherubims, two tables of stone on which the law is written. ${ }^{44}$

Willard accepted this two-sided view of the marriage relation and in his

${ }^{42}$ Ibid., pp. 16, 11.

${ }^{43}$ Benjamin Wadsworth, The Well-Ordered Family: or, Relative Duties, Being The Substance of Several Sermons About Family Prayer, Duties of Husband \& Wives, Duties of Parents \& Children, Duties of Masters \& Servants (Boston, 1712), p. 28.

${ }^{44}$ William Secker, $A$ Wedding Ring (Boston, 1690), unpaged. 
short disquisition on the family attempted to harmonize it. "Of all the Orders which are unequals," he wrote, "these do come nearest to an Equality, and in several respects they stand upon even ground. These do make a Pair, which infers so far a Parity. They are in the Word of God called YokeFellows, and so are to draw together in the Yoke. Nevertheless, God hath also made an imparity between them, in the Order prescribed in His Word, and for that reason there is a Subordination, and they are ranked among unequals." Yet, referring to the duties of the wife "as inferiour," he cautioned that "the word used there is a general word, and signified to be ordered under another, or to keep Order, being a Metaphor from a Band of Souldiers, or an Army." Further he explained that "the Submission here required, is not to be measured by the Notation or import of the Word itself, but by the Quality of the Relation to which it is applied." The husband-wife relation must never be confused with the master-servant or child-parent relation. A husband ought to be able to back his counsels with the word of God "and lay before her a sufficient Conviction of her Duty, to comply with him therein; for he hath no Authority or Compulsion." While in any relation it is the duty of inferiors to obey superiors unless a command is contrary to God, "a wife certainly hath greater liberty of debating the Prudence of the thing." Thus, the emphasis throughout is on discussion, on reasoning, on mediation. Wives as well as husbands have the responsibility to counsel and direct. Each should "chuse the fittest Seasons to Reprove each other, for things which their Love and Duty calls for." 45 The command to obedience, for Willard, was primarily a principle of order.

Sprint's sermon, bristling with assertive females and outraged husbands, is an oddity among the ministerial literature. Harmony, not authority, was the common theme. Thus, the marriage discourses support the implication of the funeral literature that women were expected to be rational as well as righteous, capable of independent judgment as well as deference, and as responsible as their spouses for knowing the word of God and for promoting the salvation of the family. A virtuous woman was espoused to Christ before she was espoused to any man.

That few tracts and sermons on childbirth survive is probably evidence in itself of the reluctance of the ministers to stress "feminine" or "masculine" themes over a common Christianity. The limited writing on parturition is worth examining, however, for here if anywhere authors had an opportunity to expound upon the peculiar failings or virtues of the weaker sex.

\footnotetext{
${ }^{45}$ Samuel Willard, A Complete Body of Divinity in Two Hundred and Fifty Expository Lectures (Boston, 1726), pp. 609-12.
} 
A pregnant woman in New England's godly community had two preparations to make for the day of her delivery. On the one hand she had to arrange for a midwife, ready a warm and convenient chamber, prepare childbed linen for herself and clothing for her infant, and plan refreshment for the friends invited to attend her. But she knew, even without a ministerial reminder, that these things could prove "miserable comforters." She might "perchance need no other linen shortly but a winding sheet, and have no other chamber but a grave, no neighbors but worms." ${ }^{46}$ Her primary duty, then, was preparing to die. Female mortality is the most pervasive theme of the childbirth literature. The elegists loved to exploit the pathos of death in birth - the ship and cargo sunk together, the fruit and tree both felled, the womb became a grave. In his poem for Mary Brown, for example, Nicholas Noyes dwelt at length on the fruitless pangs of her labor: "A BIRTH of One, to Both a Death becomes;/ A Breathless Mother the Dead Child Entombs." ${ }_{47}$ Thus, it was often in a very particular sense that the ministers spoke of the "fearful sex." In stressing the need for a husband's tenderness, for example, Willard had singled out those bodily infirmities associated with the "breeding, bearing, and nursing" of children. ${ }^{48}$

Yet these grim realities had their joyous side. Cotton Mather was fond of saying that though an equal number of both sexes were born, a larger proportion of females were reborn. ${ }^{49} \mathrm{He}$ wondered why. Perhaps they had more time to spend in godly activities, "although I must confess, tis often otherwise." No, he concluded, it was probably because in childbirth the curse of Eve had turned into a blessing. ${ }^{50}$ Given the spiritual equality of men and women, the only possible explanation for a disparity in religious performance had to be physical. Benjamin Colman resolved the same problem in a similar way in a preface to one of his sermons. Writing later in the period than Mather, he could toy with the idea of a "natural Tenderness of Spirit" given to women through the election of God, yet he too focused upon their bodily experience. Pregnancy and childbirth, by turning female thoughts frequently "towards the Gates of Death, by which We all receive our Life," increased women's susceptibility to the comforts of Christ. Pregnancy was superior to regular human ills in this regard, thought Colman, because it

${ }^{46}$ John Oliver, A Present for Teeming American Women (Boston, 1694), p. 3. This was an American edition of a pamphlet first printed in London in 1663 . The Evans film is very short and probably includes just the preface.

${ }^{47}$ Nicholas Noyes, poem for Mrs. Mary Brown in Cotton Mather, Eureka the Vertuous Woman Found, 1. 15; see also "Upon the Death of the Virtuous and Religious Mrs. Lydia Minot" (Cambridge, 1668), an anonymous broadside.

${ }^{48}$ Willard, Complete Body of Divinity, p. 611.

${ }^{49}$ See for example, Tabitha Rediviva, An Essay to Describe and Commend The Good Works of a Virtuous Woman (Boston, 1713), p. 21.

${ }^{50}$ Cotton Mather, Ornaments for the Daughters of Zion (Cambridge, 1692), p. 45. 
continued for months rather than surprising the victim with an acute attack forgotten as soon as it was over. ${ }^{51}$

Even here the ministers were ready to stress similarities between men and women. Though John Oliver urged husbands to be kind to their pregnant wives because of their increased vulnerability to "hysterical vapours," his argument really rested on an analogy, not a contrast, between the sexes. Husbands should be tolerant of their wives, he insisted, because they "desire or expect the like favour to themselves in their own sickness, wherein all men are lyable to many absurdities, and troublesome humours." ${ }^{52}$ Eve in her troubles was no more unstable than Adam.

Thus, the ministers were able to acknowledge the reproductive role of women without giving a sexual content to the psyche and soul. They stressed the experience of childbirth, rather than the nature of the childbearer. It is significant that the one place where they openly referred to the "curse of Eve" (rather than the more generalized "sin of Adam") was in dealing with the issue of birth. In such a context, Eve's curse had a particular and finite meaning, and it could be overcome. Stressing the redemptive power of childbirth, they transformed a traditional badge of weakness into a symbol of strength. Locating the religious responsiveness of women in their bodily experience rather than in their eternal nature, they upheld the spiritual oneness of the sexes. The childbirth literature, though fragmentary, is consistent with the marriage and funeral sermons.

When New England's ministers sat down to write about women, they were all interested in promoting the same asexual qualities: prayerfulness, industry, charity, modesty, serious reading, and godly writing. From 1660 to 1730 the portrait of the virtuous woman did not change. Her piety was the standard Protestant piety; her virtues were those of her brothers. Although childbearing gave her an added incentive to godliness, she possessed no inherently female spiritual qualities, and her deepest reality was unrelated to her sex. Yet an examination of the ministerial literature is not complete without consideration of an important but subtle shift, not in content but in attitude. This begins around the turn of the century in the work of Cotton Mather and continues, though less strikingly, in the sermons of Foxcroft and Colman. Mather's elegy for Mary Brown of Salem, "Eureka the Vertuous Woman Found," marks the tone:

Monopolizing HEE's, pretend no more

Of wit and worth, to hoard up all the store.

The Females too grow wise \& Good \& Great. ${ }^{.3}$

${ }^{51}$ Benjamin Colman, The Duty and Honour of Aged Women (Boston, 1711), pp. ii-iii.

${ }^{52}$ John Oliver, Teeming Women, p. 4.

${ }^{53}$ Cotton Mather, Eureka, p. 1. 
Everything Mather said about Mary Brown had been said before by other ministers about other women. But his open championship of her sex was new. All of the ministers believed in the inherent equality of men and women, but for some reason first Mather, then others, seemed compelled to say so.

If we turn to the earliest of the advice literature, Hugh Peter's $A$ Dying Father's Last Legacy, written for his daughter in 1660, this subtle shift becomes immediately apparent. The researcher who combs its tightly-packed pages looking for specific comments on women will come away disappointed. Yet the entire work is a profound comment on his attitude toward the subject. That he would write a long and detailed treatise to Elizabeth without reference to her sex is evidence in itself that he considered her basic responsibilities the same as his. Know Christ, he told her. Read the best books. Study the scriptures, using the annotations of divines. Pray constantly. Keep a journal; write of God's dealings with you and of yours with him. Discuss the workings of salvation with able friends. Seek wisdom. Speak truth. Avoid frothy words. Do your own business; work with your own hands. The one explicit reference to feminine meekness is inextricable from the general Christian context: "Oh that you might be God-like, Christ-like, Moses-like. Michael contesting with the Dragon, maintained his Meekness; and Paul says, it is the Woman's Ornament." For Peter, virtue had no gender. In putting on the woman's ornament, Elizabeth was clothed in the armor of a dragon-fighter as well. In a short paragraph on marriage, he reminded his daughter that while it was the husband's duty to lead, hers to submit, these duties "need mutual supports." Husbands and wives "need to observe each others Spirits; they need to Pray out, not Quarrel out their first Grablings; They need at first to dwell much in their own duties, before they step into each others." When he told her to stay much at home, he was applying a judgment to his own stormy career and troubled marriage. "For my Spirit it wanted weight, through many tossings, my head that composure others have, credulous, and too careless, but never mischievous nor malicious: I thought my work was to serve others, and so mine own Garden not so well cultivated." ${ }^{54}$ Thus, Peter's treatise epitomized the central sermon tradition.

Thirty years later Cotton Mather was promoting the same qualities-but with a difference. Clearly, a contrast between inherent worth and public position was at the heart of his attitude toward women. "There are People, who make no Noise at all in the World, People hardly known to be in the

\footnotetext{
${ }^{54}$ Hugh Peter, A Dying Father's Last Legacy (Boston, 1717), pp. 22, 34, 83. Lyle Koehler quotes merely the phrase "Woman's Ornament" in attempting to show that Hugh Peter shared a general Puritan belief in the subjection of women. See "The Case of the American Jezebels," p. 59.
} 
World; Persons of the Female Sex, and under all the Covers imaginable. But the world has not many People in it, that are fuller of the Truest Glory." 55 That women made no noise bothered Mather, and he was continually devising metaphorical detours around the Pauline proscriptions. "Yes, those who may not Speak in the Church, does our Glorious Lord Employ to Speak: to Speak to us, and Speak by what we see in them, such Things as we ought certainly to take much Notice of." ${ }^{56} \mathrm{He}$ made much of the fact that Abiel Goodwin, a little damsel half his age, had taught him much of salvation, and in her funeral sermon he expressed pleasure that she could finally "without any Disorder" speak in the Church. ${ }^{57}$

But there was a route to worldly honor open to women, one which no epistle denied. "They that might not without Sin, lead the Life which old stories ascribe to Amazons, have with much Praise done the part of Scholars in the World." ${ }^{58}$ A long section in Ornaments for the Daughters of Zion was devoted to the promotion of female writing. Mather combed the scriptures and the classics for precedents and applauded the efforts of near contemporaries such as Anna Maria Schurman, a Dutch feminist whose tract The Learned Maid probably influenced his decision to teach Katharin Hebrew. Schurman's argument, deeply imbedded in traditional piety, would have been congenial to Mather. She excluded from discussion "Scriptural Theology, properly so named, as that which without Controversie belongs to all Christians," directing her attention to that wider scholarship commonly denied women. If you say we are weak witted, she wrote, studies will help us. If you say we are not inclined to studies, let us taste their sweetness and you will see. If you say we have no colleges, we can use private teachers. If you say our vocations are narrow, we answer they are merely private; we are not exempt from the universal sentence of Plutarch: "It becomes a perfect Man, to know what is to be Known, and to do what is to be done." 59 She concluded by suggesting that young women be exposed from their infancy to the "encouragement of wise men" and the "examples of illustrious women." In his tracts and in his sermons, Mather enthusiastically provided both.

It is important to understand that we are not dealing with a new concept of women in Mather's work, but a new visibility. Though in 1660 under sentence of death, Peter could hardly have recommended a public role for Elizabeth, there is evidence that he was as ready as Mather to value female

\footnotetext{
${ }^{55}$ Cotton Mather, Bethiah. The Glory Which Adorns the Daughters of God and the Piety, Wherewith Zion Wishes to see her Daughters Glorious (Boston, 1722), p. 34.

${ }^{56}$ Cotton Mather, Undoubted Certainties, or, Piety Enlivened (Boston, 1720), p. 26.

${ }^{57}$ Cotton Mather, Juga, p. 24.

${ }^{58}$ Cotton Mather, Ornaments, pp. 5-6.

${ }^{59}$ Anna Maria Schurman, The Learned Maid: or, Whether a Maid may be a Scholar? A Logick Exercise (London, 1659), pp. 1, 37.
} 
scholarship and writing. In 1651 he had contributed a Prefatory letter to a revolutionary tract by Mary Cary, applauding her clear opening of the scriptures and her rejection of "naked Brests, black Patches" and "long Trains" in favor of a pen. He referred to "Two of this Sexe I have met with, very famous for more than their mother-tongue, and for what we call Learning, yet living." One of these women, "the glory of her sexe in Holland," was apparently Anna Maria Schurman, whom Peter may have met in Utrecht. ${ }^{60}$

As important as Mather's promotion of increased intellectual activity for women was the luster he gave to their more traditional roles. In beginning his funeral sermon for his own mother, he exclaimed: "Oh! The Endearments of our God! Beyond all the Endearments of the Tenderest Mother in the World!" Taking for his text Isaiah 49:15, "Can a Woman forget her Sucking Child, that she should not have Compassion on the Son of her Bowels? Yea, They may forget: yet will not I forget thee," he drew out the parallels between the love of God and the love of a mother. "The Disposition which the Glorious God has to provide for the Comfort of His People, has Two Resemblances, in His Two Testaments; And in both of them, 'tis Resembled unto the Provision which Female-Parents make for their Young-ones." Mothers comfort their children through their good instructions, through their good examples, and through their pious prayers. These, however, are temporary comforts. Mothers feed us, but God does more. Mothers clothe us, but God does more. Mothers guide us, but God does more. Mothers keep us out of harm's way, but God does more. Mothers confer ornaments upon us, but God confers upon us the lasting ornament. Thus God is a better mother than our earthly mothers. At this point, Mather drew back somewhat from his metaphor, assuring his audience that God was also our father. "What is the best of Mothers weigh'd in the Ballance with Such a Father? Our Father is now the Infinite God." But he went on:

It has been a little Surprising unto me to find That in some of the Primitive Writers, the Holy Spirit is called, The Mother. Tertullian uses this Denomination for the Holy Spirit; the Mother, who is Invocated with the Father and the Son. ${ }^{61}$

Instead of recoiling from the heresy, Mather explained the reasonableness of the metaphor. It is through the Holy Ghost that we are born again. The Holy Ghost is spoken of in the scriptures as a comforter. Surely nothing is of greater comfort than a good mother.

${ }^{60}$ The entire letter is quoted in Doris Mary Stenton, The English Woman in History (London: G. Allen and Unwin, 1957), pp. 136-37.

${ }^{61}$ Cotton Mather, Maternal Consolations of God (Boston, 1714), pp. 5, 8, 24, 25. 
Mather did not mean to deify women. In finding female as well as male virtues in the Godhead, he was simply reasserting the spiritual equality of men and women and the essentially asexual nature of godliness. But he was doing something else as well. He was openly and generously bolstering the public image of Boston's women.

If a person believes in the inherent equality of the sexes yet notes an inequity in the way they are regarded in society, he can resolve the discrepancy in three ways. He can try to change women, encouraging them to enlarge those activities which might bring them honor and recognition. He can try to change society, urging recognition and praise for the unsung activities women already excel in. Or he can dismiss the whole problem, deny the importance of status altogether, and turn his attention to the spiritual realm. Mather tried all three. In praising the works of Anna Maria Schurman and in teaching his daughter Hebrew, he put himself on the side of enlarged opportunity. In eulogizing his mother, he gave public recognition to a specifically feminine role. But as a good minister he could not commit himself completely to any worldly activity. His real commitment had to be to the glory of God. Paradoxically, then, one of the attractions of women for Mather seems to have been their very lack of status. In praising them, he was not only encouraging their good works, he was demonstrating his own superiority to earthly standards. Thus he withdrew with one hand what he had given with the other.

Mather's work points to a difficulty in reconciling inherent worth and earthly position. For most of the ministers through most of the period this had been no problem. Either they had seen no discrepancy or they were unconcerned with questions of status. The reasons for Mather's position are not entirely clear, although several explanations suggest themselves. On the one hand, he may have been influenced by European feminist thought; in a letter to his sister-in-law, who was living in England, he mentioned not only Anna Maria Schurman but Marie de Gournay. ${ }^{62}$ Yet even with an allowance for the Atlantic, the writings of neither were new. Gournay's essays were published in the 1620's, Schurman's in the 1650's. Nor was Schurman unknown to earlier ministers, as the Hugh Peter friendship shows. More probably, Mather was dealing with changes in his own provincial society. It is a commonplace that by the end of the seventeenth century, New England was becoming more secular as well as more prosperous. The presumed threat of leisure hangs over much of Mather's writing. In his first booklet, he noted that while women often had a great deal to do, "it is as often so, that you have little more Worldly Business, that to Spend (I should rather say, to Save) what others Get, and to Dress and Feed (should

\footnotetext{
${ }^{62}$ Diary of Cotton Mather, 1709-1724, Mass. Hist. Soc. Collections, 7th Series, VIII (Boston, 1911), p. 325.
} 
I not also say, to Teach) the Little Birds, which you are Dams unto. And those of you, that are Women of Quality are Excused from very much of this Trouble too." ${ }^{63}$ He picked up the same theme in his tract for midwives, urging mothers to suckle their own infants. "Be not such an Ostrich as to Decline it, merely because you would be One of the Careless Women Living at Ease." ${ }^{64}$ Clothing and jewels are pervasive metaphors not only in Ornaments for the Daughters of Zion but in Bethiah, a similar pamphlet written thirty years later. In both, women are told that if they will resist the temptation to worldly adornment they will be "clothed with the sun." 65 Perhaps changes in the provincial lifestyle gave new impetus to the traditional Puritan distrust of leisure. Such an explanation accounts for Mather's injunctions to piety and his warnings against worldliness, but it does not totally explain his preoccupation with status.

Cotton Mather's writings on women point to a much more fundamental problem, a paradox inherent in the ministerial position from the first. This paper began by noting the obvious-that New England's women could not preach, attend Harvard, or participate in the government of the congregation or commonwealth. It went on to argue that this circumscribed social position was not reflected in the spiritual sphere, that New England's ministers continued to uphold the oneness of men and women before God, that in their understanding of the marriage relationship they moved far toward equality, that in all their writings they stressed the dignity, intelligence, strength, and rationality of women even as they acknowledged the physical limitations imposed by their reproductive role. Cotton Mather may not have been fully conscious of this double view, yet all his writings on women are in one way or another a response to it. Such a position requires a balance (if not an otherworldliness) that is very difficult to maintain. In the work of his younger contemporaries, Benjamin Colman and Thomas Foxcroft, this is even more clearly seen.

Colman's daughter Jane was apparently fond of the sermons of Cotton Mather for she composed a tribute to him on his death. Certainly in her own life she exemplified his teaching, spurning balls, black patches, and vain romances for godly scholarship. She had the run of her father's library, which

\footnotetext{
${ }^{63}$ Cotton Mather, Ornaments, p. 45.

${ }^{64}$ Cotton Mather, Elizabeth, p. 35. James Axtell, The School Upon a Hill: Education and Society in Colonial New England (New Haven and London: Yale Univ. Press, 1974), pp. 7583, surveys English attitudes toward wet-nurses and speculates on colonial practice.

${ }^{65}$ Cotton Mather, Bethiah, p. 37. Declension is of course a familar theme. The sex ratio of church membership is worth further study in this regard. Robert Pope, "New England Versus the New England Mind: The Myth of Declension," Journal of Social History, 3 (1969-70), 102, argues that women were becoming less rather than more dominant after 1675 . This would undercut the easy assumption made by Andrews, "Funeral Sermons of Cotton Mather," p. 32, that women were getting more attention from ministers because men had abandoned the churches.
} 
included, in addition to edifying tomes, the poetry of Sir Richard Blackmore and of Waller. At eleven she began composing rhymes of her own and as a young bride she wrote letters to her father in verse which he sometimes answered in kind. Although intensely religious, she began to measure her own writing against a worldly as well as a heavenly scale, a tendency that must have contributed to her own self-doubts and frequent headaches. In a letter to her father, she expressed the hope that she had inherited his gifts. His answer epitomized the possibilities and the limitations of the ministerial position:

My poor Gift is in thinking and writing with a little Eloquence, and a Poetical turn of Thought. This, in proportion to the Advantages you have had, under the necessary and useful Restraints of your Sex, you enjoy to the full of what I have done before you. With the Advantages of my liberal Education at School \& College, I have no reason to think but that your Genious in Writing would have excell'd mine. But there is no great Progress or Improvement ever made in any thing but by Use and Industry and Time. If you diligently improve your stated and some vacant hours every Day or Week to read your Bible and other useful Books, you will insensibly grow in knowledge \& Wisdom, fine tho'ts and good Judgment. ${ }^{68}$

Both the "useful Restraints" and the encouragement of study are familiar themes. If Colman saw no possibility for a university education, neither did he deny her ability to profit by it. Like the other ministers, he made no attempt to extrapolate a different spiritual nature from a contrasting social role. But he fully accepted that role and expected Jane to fulfill it.

In 1735, Jane Colman Turrel died in childbirth. In her father's sermons and in the biography written by her husband, there is little to distinguish her from Katharin Mather or even Jerusha Oliver. But in a poem appended to the sermons, there is a fascinating crack in the portrait. The Reverend John Adams wrote:

Fair was her Face, but fairer was her Mind,

Where all the Muses, all the Graces join'd.

For tender Passions turn'd, and soft to please,

With all the graceful Negligence of Ease.

Her Soul was form'd for nicer Arts of Life,

To show the Friend, but most to grace the Wife. ${ }^{67}$

Negligence, softness, ease! These are concepts alien to the virtuous woman. Jane Colman had been invited into her father's library as an intellectual equal, but to at least one of her male friends she had become only that much more attractive as a drawing-room ornament. It is tempting to conclude that by 1735 , even ministers were seducing the Virtuous Woman with

${ }^{66}$ Colman, Reliquiae Turellae, p. 69.

${ }^{67}$ Ibid., p. v. 
worldly standards. But the new prosperity was not entirely to blame. As an instrument of piety, scholarship had its limits. With no other earthly outlet available, dinner-party conversation had to do.

Thomas Foxcroft was either less comfortable with the intellectual role than Mather or Colman or more concerned about its limits. In Anna the Prophetess he went to great lengths to deny the implications of his own text, arguing on the one hand that women were worthy of the title of prophet and on the other that they certainly shouldn't be allowed to speak in church. His choice of a text and title were very much in the tradition of Mather, but his handling of it betrayed a discomfort his mentor never acknowledged. When he came to write of motherhood, however, his defense of women blossomed. In his sermon for his own mother, preached in 1721, he described women as the bastions of religion in the home and the community. "At the Gap, which the Death of a wise and good Mother makes, does many times enter a Torrent of Impieties and Vices." Some mothers were simply too good for this world: God might gather them home to prevent them seeing the "Penal Evils" about to befall their children. Foxcroft's praise overlay a more conservative base. He cautioned that the death of a mother might be a punishment for loving her too much as well as for loving her too little. But his own sermon is evidence of where he felt the greater danger lay. "Indeed Children's Love and Regard to their Parents living or dead, commonly needs a Spur, Tho' the Parents too often need a Curb." ${ }^{68}$ As a good Puritan, he could not embrace mother love or any other form of human love as an unqualified good, but like Mather he was concerned that Boston's mothers receive the proper respect.

This is a crucial point. In the funeral literature there had been little mention of "motherhood" as opposed to the more generalized concept of "parenthood." Even Colman, who published a baptismal sermon entitled "Some of the Honours that Religion Does Unto the Fruitful Mothers in Israel," was unable to maintain the sex differentiation much beyond the title. If a distinction between mothers and fathers is ever made in the literature, however, it is over the issue of respect. Wadsworth felt that "persons are often more apt to despise a Mother, (the weaker vessel, and frequently most indulgent) than a Father." ${ }^{69}$ Despite its text, John Flavell's $A$ Discourse: Shewing that Christ's Tender Care of His Mother is an Excellent Pattern for all Gracious Children is about parents rather than about mothers specifically. But the one direct comment on women echoes Wadsworth: "[S]he by reason of her blandishments, and fond indulgence is most subject to the irreverence and contempt of children." 70 Thus Boston's ministers

\footnotetext{
${ }^{68}$ Foxcroft, Sermon, pp. 14, 20.

${ }^{69}$ Wadsworth, Well-Ordered Family, p. 92.

${ }^{70} \mathrm{John}$ Flavell, $A$ Discourse (Boston, 1728), p. 5.
} 
showed a concern for neglect of women well before they identified or elaborated any sex-related virtues. Foxcroft built upon this concern, but with a subtle difference. Although his mother's piety was the traditional piety, it was as a mother rather than as a Christian that she was singled out. With a new set of values, a focus upon tenderness and love rather than on godliness and strength, Foxcroft's effusiveness would be indistinguishable from nineteenth-century sentimentality.

Thus, in New England sermons firmly rooted in the reformed tradition of the seventeenth century, we can see developing, as if in embryo, both the "genteel lady" of the eighteenth century and the "tender mother" of the nineteenth. Adams' poem for Jane Turrel shows the short step from Puritan intellectuality to feminine sensibility. Foxcroft's eulogy for his mother demonstrates how praise for a single virtue might obliterate all others. If Puritan piety upheld the oneness of men and women, Puritan polity in large part did not. Nor, we assume, did the increasingly mercantile world of early eighteenth-century Boston. Unwilling or unable to transfer spiritual equality to the earthly sphere, ministers might understandably begin to shift earthly differences to the spiritual sphere, gradually developing sexual definitions of the psyche and soul.

It is important to remember here that the sermon literature deals with a relatively small group of people, that it reveals attitudes not practices. Presumably, few women experienced the conflicts of Jane Turrel. Most housewives in provincial Boston were probably too occupied with the daily round to consider the nature of their position in society. Yet when a minister of the stature of Cotton Mather assumes a defensive tone, telling us that "those Handmaids of the Lord, who tho' they ly very much Conceal'd from the World, and may be called The Hidden Ones, yet have no little share in the Beauty and the Defence of the Land," as historians we ought to listen to him. ${ }^{71}$ Attitudes are important. Subtle shifts in perception both reflect and affect social practice. Mather's advocacy of women suggests a real tension in early eighteenth century New England between presumed private worth and public position. It demonstrates the need for closer study of the actual functioning of women within congregation and community. But it has ramifications beyond its own time and place. Mather's work shows how discrete and ultimately confining notions of "femininity" might grow out of a genuine concern with equality. Finally, the ministerial literature to which it belongs illustrates the importance of the narrow study, the need to move from static concepts like "patriarchal New England society" to more intricate questions about the interplay of values and practice over time. Zion's daughters have for too long been hidden.

${ }^{71}$ Cotton Mather, El-Shaddai, p. 31. 